\title{
RECENT DEVELOPMENTS IN THE INCOME TAXATION OF OIL AND GAS PROFITS
}

\author{
J. H. G. ROCHE*
}

\begin{abstract}
Income tax developments continue to play a key role in oil and gas law. Directed to lawyers who are not specialists in oil and gas taxation, this paper describes the fundamentals of the current oil and gas taxation system, and discusses recent legislative and judicial alterations to the system.
\end{abstract}

\section{INTRODUCTION}

The objective of this paper is to set forth selected income tax developments relating to the oil and gas industry which have occurred in the past year. Particular emphasis will be placed upon the legislation arising from the March 31, 1977 federal budget and the announcements made in the April 10, 1978 federal budget. The first portion of the paper will review the fundamentals ${ }^{1}$ of the federal system of oil and gas taxation, while the second will deal with the developments themselves.

\section{OVERVIEW OF THE PRESENT SYSTEM}

The four principal components of the present2 resource tax system are as follows:

1) The income tax results of the acquisition and disposition of Canadian resource properties;

2) the tax recognition of exploration or development expense;

3) the earned depletion deduction; and

4) the resource allowance deduction.

\section{A. Disposition of Resource Properties}

In general terms," the cost4 of acquiring a "Canadian resource propertys" is tax-recognized through the characterization of this cost as an expense called Canadian development expense. ${ }^{6}$ The undeducted balance of a taxpayers' Canadian development expense is deductible at

*Barrister and Solicitor, Thorsteinsson, Mitchell, Little, O'Keefe \& Davidson, Vancouver, British Columbia and Thorsteinsson \& Company, Edmonton, Alberta.

1. This paper does not purport to review in any detail the federal system of oil and gas taxation. For complete descriptions of the system, see Verchere and Donaghey, Structuring Resource Property Ventures, January (1975) 23 Can. Tax. J. 1, and Carten, Federal Income Taxation of Oil and Gas Operations (1977) 16 Alta.L.Rev. 455, Petroleum Law Supplement.

2. The present system is taken to be the legislative scheme in place after May 6, 1974.

3. Traders in resource properties are taxed on a different basis by virtue of subsection 66(5), Income Tax Act. R.S.C., 1970, c. 1.5 as amended (referred to hereafter as "the Act" or "I.T.A.").

4. As will be later described, the cost of a Canadian resource property includes any first time bonus payment.

5. See paragraph $66(15)(\mathrm{c})$ which basically provides, insofar as the definition is concerned with oil and gas rights, that a Canadian resource property is property acquired after 1971 including any right, licence or privilege to explore for, drill for or take petroleum natural gas or other related hydrocarbons in Canada, any oil or gas well situated in Canada, and any rental or royalty computed by reference to the amount or value of production from an oil or gas well situated in Canada.

6. I.T.A., paragraph 66.2(5)(a). 
$30 \%$ per annum from income from any source. The proceeds of disposition of a Canadian resource property are first applied 7 to reduce or eliminate any balance in the cumulative Canadian development expense account." Any excess is included" directly in the income of the vendor of the Canadian resource property. A reserve 10 is available to the extent of the lesser of the amount so included in income and the amount not due to the vendor until after the end of the taxation year of disposition.

\section{B. Canadian Exploration Expense, Canadian Development Expense}

The rules" which define and provide for the deduction of resource expenses are the key to the federal system of resource taxation. The definitions apply only to expenses incurred in Canada after May 6, 1974. Similar expenses incurred prior to that date and foreign expenses receive separate treatment.

Development expenses include drilling or converting a well in Canada for the disposal of waste liquids from an oil or gas well, drilling an oil or gas well in Canada, building a temporary access road to the well or preparing a site in respect of the well to the extent that this is not a Canadian exploration expense, drilling or converting a well in Canada for the injection of water or gas to assist in the recovery of petroleum or natural gas from another well, or drilling for water or gas in Canada for injection into a petroleum or natural gas formation. As mentioned above, the cost of any Canadian resource property is also recognized as a development expense. Once so characterized, a Canadian development expense is included in the above mentioned cumulative Canadian development expense account. Deduction at the $30 \%$ per annum rate 12 is taken for Canadian development expense incurred through the cumulative account. Generally, this account is increased by all Canadian development expense incurred, and decreased by deductions for development expense in prior taxation years and the proceeds of disposition of certain resource properties.

The definition of Canadian exploration expense is concerned with exploratory work rather than development activities. It is broadly drafted and in general terms includes any outlay or expense that is a geological, geophysical or geochemical expense incurred in Canada, or any expense incurred 13 in drilling an oil or gas well in Canada if the well is the first well capable of production in commercial quantities from an accumulation of petroleum or natural gas not previously known to exist, or if the drilling results in a dry hole. Again, there is

7. I.T.A., subsections $59(1.1)$ and (3.1), and subparagraph 66.2(5)(b)(v).

8. I.T.A., paragraph $66.2(5)(b)$.

9. I.T.A., subsection $66.2(1)$ and paragraph $59(3.2)(\mathrm{c})$.

10. 1.T.A., subsection 64(1.1).

11. I.T.A., paragraphs $66.1(6)(\mathrm{a})$ and $(\mathrm{b})$, and $66.2(5)(\mathrm{a})$ and $(\mathrm{b})$.

12. I.T.A., subsection 66.2(2). But note that in certain circumstances, when shares described in section 66.3 are sold, the development expense deduction is increased.

13. Revenue Canada's present administrative practice would appear to be that for an expense to be incurred in drilling an oil or gas well the actual drilling must be commenced rather than the mere payment of funds or the agreement to pay the funds having been made. For the ordinary meaning of "incurred". see Pickle Crow Gold Mines v. M.N.R., 55 D.T.C. 1001 : [1954] C.T.C. 390. This administrative practice may well not have the same application to expenses described in subparagraph 66.1(6) (a)(i). 
an account called the cumulative Canadian exploration expense account which generally records the undeducted balance of Canadian exploration expense available for deduction by the taxpayer. Canadian exploration expense must be deducted 14 by corporations principally involved in resource activities at the rate of $100 \%$ per annum provided the corporation has sufficient income; taxpayers not so involved may deductis such of their exploration expense as has been incurred between May 25, 1976 and before July 1, 1979 at 100\% per annum. The remainder is deductible at the rate of $30 \%$ per annum.

\section{Earned Depletion}

The third main element of the resource tax system is earned depletion.16 This deduction has been the subject of recent legislative activity which will be discussed later. The earned depletion deduction requires the earning of the deduction by incurring certain exploration or development expenses. One third of these costs constitute an amount termed the earned depletion base.17 This earned depletion base can be carried forward indefinitely and may be deducted in computing the income of the taxpayer, provided that in any year the deduction cannot exceed $25 \%$ of the taxpayer's resource profits ${ }^{18}$ earned in Canada in that year.

Almost all Canadian exploration and development expenses ${ }^{19}$ (or what would have been such expenses if incurred after 1971) laid out after November 7, 1969, Canadian development expense and Canadian exploration expense qualify for inclusion in the earned depletion base in an amount equal to $\$ 1$ for every $\$ 3$ spent. The main non-qualifying outlay is an amount paid to acquire a Canadian resource property. As explained above, ordinary earned depletion claimed cannot exceed $25 \%$ of resource profits as defined in the regulations to the Income Tax Act. ${ }^{20}$ Briefly, oil and gas resource profits consist of realized gains from the disposition of resource properties, income from the production of oil and gas in Canada, and rentals or royalties computed by reference to the amount or value of production from oil or gas wells in Canada.

\section{Resource Allowance}

In addition to the earned depletion deduction, taxpayers with Canadian resource profits in a year are entitled to deduct in that year an amount referred to as a resource allowance. ${ }^{21}$ The deduction is $25 \%$ of resource profits (other than profits from the dispositions of resource properties) calculated after deducting operating costs and capital cost allowance but before deducting interest, exploration or development expenses, or depletion.

The resource allowance can be viewed as a consequence of the May 1974 federal budget which resulted in a disallowance of provincial

14. I.T.A., subsection $66.1(2)$.

15. I.T.A.. subsection 66.1(3).

16. I.T.A., section 65 and Regulation 1200.

17. Regulation 1205.

18. Regulation 1204.

19. I.T.A., paragraph $66(15)(\mathrm{b})$.

20. R.S.C. 1970 , c. I-5, as amended.

21. I.T.A., paragraph $20(1)(v .1)$ and Regulation 1211. 
royalties as deductions in computing income. Up until May 6, 1974 these provincial royalties had been deductible expenses. The provincial royalties had become so significant in amount that they were reducing income for federal tax purposes to a level which the federal authorities viewed as unacceptably low. In order to protect its tax base, the federal government disallowed royalties as a deduction. As partial recognition of the increased tax burden on natural resource taxpayers, a specially abated rate of corporate tax 22 on income from resource ventures was initially allowed. Generally effective January $1,1976,23$ this abatement of tax was replaced with the resource allowance.

\section{RECENT DEVELOPMENTS}

\section{A. The Queen v. Alberta and Southern Gas Co. Ltd.24}

The facts placed before the Federal Court of Appeal were that Alberta and Southern was engaged in acquiring natural gas in Alberta and reselling it to an associated company in California. In 1972 the company derived $\$ 4,000,000$ from its sales of gas to the associated company which, in the normal course, would have been included in Alberta and Southern's income for the year subject to tax. Rather than face this prospect, Alberta and Southern concluded a "carve-out" agreement with Amoco Petroleum Company whereby Alberta and Southern paid Amoco \$4,000,000. In return, Amoco assigned to Alberta and Southern a working interest in certain lands, which working interest met the definition of a Canadian resource property. Alberta and Southern was entitled to hold the working interest forever subject to a provision that the working rights would end when Alberta and Southern received

(a) petroleum substances to the value of $\$ 4,000,000$ plus interest, or

(b) the amount of $\$ 4,000,000$ plus interest.

In approximately one year Amoco paid Alberta and Southern $\$ 4,000,000$ plus interest. In the Federal Court, Trial Division, Mr. Justice Cattanach in reviewing the evidence at the trial stated:25

Both Mr. Goudie and Mr. Clark who are officers of the plaintiff, were called as witnesses and candidly admitted that the motive of the plaintiff for entering into these "carve-out" agreements with Amoco was to remove the two amounts of $\$ 4,000,000$ which would have been taxable as income in the 1972 and 1973 taxation years from the grasp of the tax collector to preserve these amounts which were dedicaled for exploration and development expenses and to use these moneys at some future time in a much more direct, active and realistic way for that purpose than by resort to carve-out agreements.

The issue was whether the $\$ 4,000,000$ paid in 1972 by Alberta and Southern was deductible by that company in 1972 as a Canadian

22. I.T.A., repealed section 124.2 .

23. Note that resource corporations with 1976 taxation years straddling January 1,1976 were entitled to the resource allowance in respect of the entire year's resource profits and, in addition, were entitled to the abated rate of tax on taxable production profits relating to the 1975 portion of their 1976 taxation years. On the other hand, individuals with similar fiscal periods were required to reduce their resource allowance on a number of days in 1975 as against a number of days in 1976 basis. Individuals were not entitled to the abated rate of tax on oil and gas profits.

24. The Queen v. Alberta and Southern Gas Co. Ltd. 77 D.T.C. 5244, [1977] C.T.C. 388 (F.C.A.).

25. Alberta and Southern Gas Co. Ltd. v. The Queen [1976] C.T.C. 639 at 650-651. 
exploration and development expense and more specifically as constituting the cost to Alberta and. Southern of a Canadian resource property. The government argued that the normal tax provisions were overridden by subsection 245(1) of the Act which reads as follows:

245(1). In computing income for the purposes of this Act, no deduction may be made in respect of a disbursement or expense made or incurred in respect of a transaction or opera. tion that, if allowed, would unduly or artificially reduce the income.

Mr. Justice Jackett disposed of the issue in favour of Alberta and Southern with the following statements: 26

When one reads section 66, one finds that one of the things that is permitted is a deduction of the cost of a "Canadian resource property" and, when one reads section 59 and paragraph $12(1)(\mathrm{g})$, one finds that the proceeds of disposition of such a property must be brought into income. These provisions for deduction and taxation of capital amounts seem to me to have the obvious purpose of encouraging taxpayers to put money into such resource properties and keep it there. That being what the provisions seem to have been intended to encourage, as it seems to me, a transaction that clearly falls within the object and spirit of section 66 cannot be said to unduly or artifically reduce income merely because the taxpayer was influenced in deciding to enter into it by tax considerations.

The decision has been appealed to the Supreme Court of Canada with argument to take place in September and judgement expected sometime in December.

This decision must be taken to be a test of the strength of subsection 245(1). In a decision of the Supreme Court of Canada noted by Mr. Justice Jackett, Harris v. M.N.R., 27 Cartwright, J. referred to the identically worded forerunner of subsection $245(1)$, and stated: 28

If, contrary to the views I have expressed, we had accepted the appellant's submission that
the transaction embodied in the lease was one to which Section 18 applied and that on the
true construction of the lease and the terms of that section the appellant was prima facie
entilled to make the deduction of the capital cost allowance of $\$ 30,425.80$ claimed by him,
I would have had no hesitation in holding that it was a deduction in respect of an expense
incurred in respect of a transaction that if allowed would artifically reduce the income of the
appellant and thal consequently its allowance was forbidden by the terms of Section 137(1).
The words in the subsection "a dishursement or expense made or incurred" are, in my
opinion, apt to include a claim for depreciation or for capital cost allowance, and if the lease
were construed as above suggested the arrangement embodied in it would furnish an
example of the very sort of "transaction or operation" at which section 137(1) is aimed.

In noting this extract from Harris, Mr. Justice Jackett underlined the fact that subsection 245(1) remains to be reckoned with. But he also brought in the notion that sections 59 and 66 are incentive sections which afford unusually generous tax results in order to encourage taxpayers to invest in Canadian resource properties. He appears to say that if taxpayers respond to incentive legislation and conduct a transaction which clearly falls within the object and spirit of the incentive legislation, subsection 245(1) cannot be applied merely because the taxpayer was influenced by tax considerations.

In determining the likelihood of a subsection $245(1)$ assessment, a taxpayer will receive little guidance by reading this decision. He will often have difficulty in deciding what is or is not incentive legislation, and whether or not his proposed transaction falls within the object and spirit of the legislation. In almost all cases one would assume the taxpayer would be influenced by tax considerations in deciding to enter into a transaction.

26. The Queen v. Alberta and Southern Gas Co. Ltd. [1977] C.T.C. 388 at 397 (F.C.A.).

27. Harris v. M.N.R. [1966] S.C.R. 489, [1966] C.T.C. 22666 D.T.C. 5189.

28. Harris v. M.N.R. [1966] C.T.C. 226 at 241. 
The decision of the Supreme Court of Canada with respect to this issue will be of considerable interest.

\section{B. Legislative Developments}

1) March 31, 1977 Budget

Unlike the May 6, 1974 and November 18, 1974 federal budgets, which had enormous impact on the oil and gas industry, the resource tax revisions in the spring 1977 federal budget had little real economic effect on the industry. There were, however, a number of important technical changes to the rules.

\section{(a) Adjustment to Royalty Disallowance Rules}

The provisions of the Income Tax Act which include and retain in income royalty payments made to a provincial government are found in paragraphs $12(1)(0)$ and $18(1)(\mathrm{m}) \cdot 2^{4 \prime}$ Paragraph $12(1)(0)$ is intended to ensure that royalties collected by a province in kind are not excluded from the producer's income. Paragraph $18(1)(\mathrm{m})$ precludes any deduction for Crown royalties paid by a taxpayer. Prior to the recent amendments, the provisions, read literally, prevented the deduction of any royalty or equivalent amount paid to any corporation controlled by Her Majesty in right of Canada or a province. Therefore, an oil and gas company engaged in an ordinary commercial venture with a Crown corporation technically ran the risk of being taxed on the royalty payments. The paragraphs were amended by Bill C-11, effective May 6,1974 , so that only royalties and like amounts paid to the Crown, the Crown's agent or a Crown corporation by virtue of an obligation imposed by statue will be disallowed as a deduction from income.

\section{(b) Successor Corporation Rules}

The Income Tax Act and Regulations provide rules permitting one corporation to transfer to another undeducted balances of Canadian exploration and development expenses, 30 foreign exploration and development expenses,"31 Canadian exploration expense,32 Canadian development expense, 3 drilling and exploration expenses incurred before 1972 on or in respect of exploring or drilling for petroleum or natural gas in Canada, ${ }^{34}$ and earned depletion. ${ }^{33}$ The balances so transferred can be deducted on a restricted basis by the second corporation. Prior to the March 1977 federal budget, the rules contained several drafting errors and difficult language. The new rules have corrected most of the technical deficiencies and, in addition, made some substantive changes to the manner of the application of the provisions.

Prior to March 31, 1977 the successor corporation rules came into play whenever all, or substantially all, 36 of the assets used by a corporation (predecessor corporation) in carrying on its business in Canada were acquired by purchase or otherwise (including amalgama-

29. There are royalty disallowance provisions in section 69 as well.

30. I.T.A., subsections $66(6)$ and (7).

31. I.T.A., subsections $66(8)$ and (9).

32. I.T.A., subsections $66.1(4)$ and (5).

33. I.T.A., subsections $66.2(3)$ and (4).

34. Income Tax Application Rules, 1971, subsections 29(25) and (29) and 34(3).

35. Regulation 1202(2) and (3).

36. See Wardean Drilling Co. Ltd. v. M.N.R., 78 D.T.C. 6202. 
tions pursuant to section $877^{37}$ or section 88 liquidations) by a second corporation (successor corporation). The successor corporation could then deduct the predecessor's exploration or development expenses but only to the extent of income from the predecessor corporation's properties owned by the predecessor immediately prior to the acquisition. If a third corporation (second successor corporation) acquired the assets of the successor corporation, the exploration and development accounts of the predecessor corporation passed through to the second successor to be deducted against income from the predecessor corporation's properties. With respect to the successor corporation's own exploration and development accounts and income, the second successor corporation was a successor corporation and the successor corporation was a predecessor corporation.

The following substantive changes have been made.

The old provisions required that for the expenses to be preserved the successor corporation had to acquire all or substantially all of the property of the predecessor corporation used by it in carrying on its business in Canada. The new rules will require only the acquisition of all or substantially all of the predecessor's resource business properties.

In the case of exploration expense, the pre-1977 budget provisions provided for the successor corporation being either a principal or a non-principal-business corporation. The principal-business corporation could write off the carried across exploration expense at $100 \%$ per annum, while the non-principal-business corporation was restricted to only 30\% per annum. This restriction recognized that until the 1976 budget, non-principal-business taxpayers could only write off their own exploration accounts at $30 \%$ per annum. That rate in respect of the taxpayers' own accounts has been raised to $100 \%$ for all taxpayers, provided, in the case of non-principal-business taxpayers, the exploration expense is incurred between May 25, 1976 and July 1979. The new successor corporation rules, in keeping with the initiative taken in the 1976 budget to allow all taxpayers the same rate of write-off for exploration expense, will remove any distinction in write-off rate at the successor corporation level.

The new rules will allow income arising from the disposition by the successor corporation of resource properties previously owned by the predecessor corporation to be reduced by the amount of the predecessor corporation's exploration or development accounts. This type of income could not be so reduced in past years. It should be noted that the proceeds will first be applied to the successor corporation's own development account. Any income arising will then be reduced by the predecessor corporation's exploration and development expenses.

The final policy change relates to the old rule which required the predecessor to have a right to take or remove petroleum or natural gas from the property before the income from that property qualified as income which could be offset by the carried-across exploration and development expenses. This caused a problem where a predecessor

37. On an amalgamation, for purposes of the successor corporation rules, there will be two predecessor corporations and the amalgamated company will be the successor corporation. 
corporation had an interest in a resource property but for one reason or another did not have a right to take in respect of that property. This was thought to be an inappropriate result and has been corrected by adding the broader phrase "an interest" to the present words "right to take or remove".

\section{(c) Saskatchewan Net Royalty Leases}

In the past, Saskatchewan has employed a type of oil and gas lease known as a net royalty lease. The leases could be acquired without the payment of a bonus. but subsequent royalty payments were higher to compensate for this fact. Because first time bonus payments are deductible as Canadian development expense while royalty payments are not, adjustment has been made to subparagraph $66.2(5)$ (a)(iii) to recognize as development expense that portion of Saskatchewan net royalty lease payments which can be considered to be in lieu of the bonus payment.

\section{(d) Resource Property Dispositions by Partnerships}

Prior to March 31, 1977 the rules taxing the proceeds of disposition of a resource property sold by a partnership did not function satisfactorily. Under the Income Tax Act, income from partnership activities is generally calculated at the partnership level with the related expenses, capital cost allowances and other deductions taken in the course of that income calculation. The net income of the partnership is then allocated to the partners to be taxed in the partners' hands. Although the combined effect of pre-March 31, 1977 paragraph 96(1)(d) and corresponding provisions ${ }^{38}$ contained in the definitions of various resource expenses altered the above general rule and required resource deductions to be claimed at the partner level rather than the partnership level, the rules in sections 59 and 66.2 ignored this fact by requiring the disposing taxpayer (in this case the partnership) to reduce its cumulative development expense account by the proceeds of disposition. Prior to the amendment, there was some doubt as to whether or not a partnership had a cumulative development account and, if so, the amount and function of the account.

Amended paragraph $96(1)(d)$ and new subsection $66.2(6)$ have corrected this by, in effect, eliminating the partnership from the sections 59 and 66.2 calculations and instead requiring these calculations to be made at the partner level.

\section{(e) Change of Control}

Subsection 66(11) and similar provisions in the Regulations ${ }^{39}$ as they applied to acquisitions of control prior to March 31, 1977 provided that where control of a corporation had, after 1971 and between a time when the corporation ceased to carry on active business and a time when it commenced to carry on active business again, been acquired by a person or a person and other persons with whom that person did not deal at arm's length and who did not control the corporation at the time when it so ceased to carry on active business, all of its post1971 undeducted resource deductions and its earned depletion base were erased. This rule was easily circumvented by arranging to have

38. I.T.A., subparagraphs 66.1(6)(a)(iv), 66.2(5)(a)(iv), 66(15)(b)(iv) and 66(15)(e)(iv).

39. Regulation 1202(1). 
the corporation recommence active business prior to the change of control. The apparent purpose of the provision was to prevent trading in undeducted resource expenses which have a tax value.

The amended subsection precludes this circumvention by providing that a new acquisition of control at any time after the cessation of active business will result in the elimination of undeducted post-1971 resource expenses. In addition, the rules have been changed slightly in scope. They now apply when a person or persons acquire control; previously, they came into play when a person or a person and other persons with whom that person did not deal at arm's length acquired control.

\section{(f) Sulphur Production in the Course of Processing Natural Gas}

The processing ${ }^{40}$ of natural gas effluent in a gas processing plant is a manufacturing and processing undertaking for the purposes of the Income Tax Act. Thus, the profits from the processing are subject to a lower rate of $\operatorname{tax}^{41}$ and capital cost allowance can be taken at incentive rates ${ }^{42}$ with respect to most of the depreciable property used in the undertaking. Prior to March 31, 1977, to the extent sulphur was produced during the course of the gas processing, the depreciable property in the plant and the profits from the plant did not qualify 43 for the manufacturing and processing tax incentives. The technical reason for the exclusion was that sulphur is an industrial mineral and the production of industrial minerals was expressly excluded from the manufacturing and processing incentives. This exclusion was almost undoubtedly written into the Act simply to preclude the more conventional production of industrial minerals such as sulphur from receiving the manufacturing and processing incentives. It was not intended to so remove this kind of sulphur production which in most cases is a necessary offshoot of natural gas processing.

The amendment to subparagraph $125.1(3)(b)$ (vii) will correct the situation effective for the 1977 and subsequent taxation years.

\section{(g) Ordering of Deductions}

Because of the piecemeal evolution of the resource tax rules, a multitude of different pools or categories of deductions in respect of resource expenses has arisen. For example, a taxpayer drilling an oil or gas well in 1973 might well have incurred a Canadian exploration and development expense. If the identical well had been drilled in 1976 it might have been a Canadian development expense or a Canadian exploration expense. Similarly, if a corporation has acquired all the property of a second corporation used in carrying on a resource business, the undeducted balances of the second corporation's resource expense accounts will be deductible by the acquiring corporation as successor corporation expense. In this fashion, it is possible for a resource corporation to accumulate 26 different categories of resource deductions all earned in slightly different circumstances.

40. For the meaning of "processing" in this context. see Texaco Exploration Company v. The Queen [1975] C.T.C. 404, 75 D.T.C. 5288.

41. I.T.A., section 125.1 .

42. Class 29.

43. I.T.A. subparagraph 125.1(3)(b)(vii) and Regulation 1104(9). 
Until the March 31, 1977 budget, the order in which these various pools of expenses were to be deducted was not ascertainable from the legislation. This uncertainty has not been resolved and the ordering would appear to be as set out in Appendix A.

\title{
(h) Frontier Depletion
}

The Budget Document issued March 31, 1977 contained the following statement with respect to frontier depletion:44

\begin{abstract}
In present circumstances a fuller knowledge of Canada's petroleum and natural gas production potential is essential. To date, however, there has not been the level of exploration activity in Canada's frontier areas, particularly in deep water, to provide this knowledge. There are a number of reasons for this including the high costs of offshore exploration, the attractiveness of drilling for more accessible reserves, and an absence of any major new discoveries. Geologists have indicated, however, that the formations in Canada's frontier areas suggest the possible existence of further significant oil and gas deposits. An incentive to encourage exploration in these areas of Canada is appropriate at this time.

Additional encouragement will be provided to taxpayers in respect of drilling costs in excess of \$5 million incurred in connection with an exploratory well. The well must be located in Canada, including the continental shelf, and the expenses must be incurred between March 31, 1977 and April 1, 1980.

The incentive will take the form of an additional earned depletion entitlement of $66 \%$ per cent of qualifying drilling costs. A taxpayer will be entitled to offset this additional depletion against income from any source, whereas normal depletion is deductible only to the extent of 25 percent of resource profits. This latter feature should attract the participation of investors who have not previously been involved in resource exploration.
\end{abstract}

The Regulations ${ }^{45}$ have now been amended and are relatively straightforward. It is somewhat surprising to note that to the extent that a taxpayer expends funds which qualify for the frontier exploration base, he will be earning deductions from income equivalent to $200 \%$ of the expense incurred. The deductions will be comprised of $100 \%$ for Canadian exploration expense, $33 \frac{1 / 3}{3} \%$ for ordinary earned depletion and $662 / 3 \%$ for frontier depletion. This must be viewed as an extremely strong incentive.

The deduction consists of such amount as the taxpayer may claim ${ }^{46}$ which does not exceed the lesser of his income for the year and his frontier exploration base. The frontier exploration base must be determined separately for each oil and gas well. As described by the Budget Document, it consists of $66^{2} / 3 \%$ of the amount by which Canadian exploration expense incurred with respect to the well after March 1977 and before April 1980 exceeds $\$ 5,000,000$.

\section{2) April 10, 1978 Budget}

The incentive offered to resource companies in order to encourage them to participate in non-conventional oil and gas projects has been expanded by the most recent federal budget. In his budget speech, Mr. Chretien stated:47

We must also continue to place high priority on our national energy policy, and in particular the need to extend self-reliance for oil and gas. We are fortunate in our existing and potential resources, and many tax incentives and other measures have been put in place to encourage their development. But increasing attention is now focussed upon the heavy oil

44. Canada, Department of Finance, Budget Document 33 (1977).

45. Regulation 1207.

46. The flexibility of the amount of the deduction for frontier depletion can be contrasted with the deduction for ordinary depletion which must be taken or lost.

47. (1978) 121 H.C. Deb. No. 92, 4317. 
reserves and oil sands deposits of the western provinces which can be tapped only by advanced technology and multi-billion dollar investments. These are projects requiring long lead times for planning, onganization, design and construction. It is important to get them moving now, and I have concluded that some modification and clarification of their tax treatment can be helpful in that regard.

First, I want to make clear that the up-grading plants to process the heavy oil produced from wells into a type of oil similar to conventional crude will be treated as a manufacturing facility, eligible for fast write-offs and the reduced tax rate.

Second, it will be important to extract as much oil as technologically possible from all deposits. It has already been established that enhanced recovery systems can greatly increase total production. After today, therefore, special machinery, equipment and other facilities acquired for enhanced recovery systems - specifically, so-called "Tertiary" recovery - will be able to earn depletion at a rate of $\$ 1$ for every $\$ 2$ of expenditure as compared to the normal earning rate of $\$ 1$ for $\$ 3$.

Finally, earned depletion may be applied at present only to reduce taxable resource profits, and only up to a ceiling of 25 per cent. This provision will be significantly improved. Effective immediately, corporations may deduct depletion earned through certain qualifying invest. ment in non-conventional oil projects up to the extent of 50 per cent of total income - both resource and other profits. The qualifying investment will include expenditures on tertiary recovery equipment and certain depreciable property acquired for use in a bituminous sands mining project.

The Regulations bringing into force the budget measures will not be released for some months. Accordingly, little precise information is currently available. It is worthwhile to note, however, that the incentives have continued on the theme developed with respect to the frontier exploration base, namely, that the enriched depletion base earned by the expenditures will be deductible from income from all sources and not just the taxpayer's resource profits which is the case with ordinary earned depletion. Undoubtedly this is intended to encourage investors who do not otherwise become involved in resource projects to realize the benefits of the depletion deduction without awaiting profit from the project.

\section{CONCLUSION}

The objective of the recent Income Tax Act amendments is to encourage investment in non-conventional oil and gas ventures as well as to clear up remaining technical problems. It remains to be seen whether investors will respond to the very substantial tax benefits offered by the government. In any case, the climate has clearly changed for the Canadian oil industry from the apparent period of confrontation of several years ago.

\section{APPENDIX A}

\section{ORDER OF RESOURCE DEDUCTIONS}

1. Second successor corporation Canadian development expense

$66.2(4)$

2. Successor corporation Canadian development expense

3. Canadian development expense

4. Expenses of special product corporations

5 . Old amalgamation expenses

6. Second successor corporation, drilling and exploration expense and prospecting
$66.2(3)$

$66.2(2)$

66(2)

ITAR 34(3) 
exploration and development expense

ITAR 29(29)

7. Second successor corporation Canadian exploration and development expense

$66(7)$

8. Second successor corporation Canadian exploration expense

$66.1(5)$

9. Successor corporation drilling and exploration expense and prospecting exploration and development expense

ITAR 29(25)

10. Successor corporation Canadian exploration and development expense

$66(6)$

11. First successor corporation Canadian exploration expense

$66.1(4)$

12. Partnership drilling and exploration expense - 1948-1962

ITAR 29(9)

13. Partnership drilling and exploration expense - 1962-1972

ITAR 29(10)

14. Non principal-business drilling and exploration expense and prospecting exploration development expense - 1962 1972

ITAR 29(11)

15. Individual drilling exploration expense

ITAR 29(12)

16. Petroleum corporation drilling or exploration expenses - 1949-52

ITAR 29(1)

17. Mining corporations prospecting exploration and development expense - 1952

ITAR 29(2)

18. Petroleum and mining corporations drilling and exploration expense and prospecting exploration and development expense - 1952-1962

ITAR 29(3)

19. Principal-business corporations drilling and exploration expenses and prospecting exploration and development expense incurred between 1953 and 1972 and undertaken in return for shares

ITAR 29(24)

20. Principal-business corporations drilling and exploration expense and prospecting exploration and development expense 1962-1972

21. Second successor corporation foreign exploration and development expense

ITAR 29(4)

$66(9)$

22. First successor corporation foreign exploration and development expense

$66(8)$

23. Foreign exploration and development expense

$66(4)$

24. Canadian exploration and development expense

$66(1)$ or $66(3)$

$66(2)$ or $66.1(3)$

25. Canadian exploration expense

26. Earned depletion

65 . 